\title{
Market maketh magic - consequences and implications of market choice for frugal innovation
}

\section{Lukas Neumann*, Stephan Winterhalter and Oliver Gassmann}

\author{
Institute of Technology Management, \\ University of St. Gallen, \\ Dufourstrasse 40a, 9010 St. Gallen, Switzerland \\ Email: Lukas.Neumann@hsgalumni.ch \\ Email: Stephan.Winterhalter@hsgalumni.ch \\ Email: Oliver.Gassmann@unisg.ch \\ *Corresponding author
}

\begin{abstract}
This study systematically analysed 237 frugal innovation cases in order to understand the consequences and implications of market choice on the characteristics of a successful frugal innovation. The results demonstrate that this type of innovation is disruptive to its respective target market. Further, the study shows that firms that want to achieve such innovation tend to focus either on activities along the value chain or the solution (product/service) itself. This distinction yielded four clusters of frugal innovation, which are described in detail, including aspects regarding strategy, organisation, processes and technology.
\end{abstract}

Keywords: frugal innovation; resource-constrained innovation; emerging markets; developing markets; bottom of the pyramid; emerging middle class; disruption; low-end disruption; new market disruption.

Reference to this paper should be made as follows: Neumann, L., Winterhalter, S. and Gassmann, O. (2020) 'Market maketh magic consequences and implications of market choice for frugal innovation', Int. J. Technology Management, Vol. 83, Nos. 1/2/3, pp.55-77.

Biographical notes: Lukas Neumann completed his $\mathrm{PhD}$ at the University of St. Gallen in 2019 and worked as a Visiting Researcher at the University of Cambridge. His work focuses on innovation for emerging and developing markets, specifically frugal innovation. His research has been published in Technovation and Int. J. Technology Transfer and Commercialisation among others.

Stephan Winterhalter is a Regional Sales Manager at Hilti Corporation in Switzerland. He completed his PhD at the University of St. Gallen in 2015 and worked as a Visiting Researcher at the IESE Business School in Barcelona. His work focuses on business models and emerging markets. It has been published in Small Business Economics, Technovation, R\&D Management among others.

Oliver Gassmann is a Professor of Technology Management at the University of St. Gallen. After completing his PhD, he led the R\&D Department at Schindler Group in Switzerland. His research focuses on the question of how companies innovate and achieve competitive advantage from this. He has published in various leading journals such as Research Policy, Technovation, Journal of Management and Long Range Planning. 


\section{Introduction}

Drawing on an old English proverb, William Horman once wrote 'manners maketh man' (Vulgaria uiri doctissimi, 1519), implying that the essence of men is defined by manners. Undoubting, one could argue a similar tie exists between firms and innovation. With this in mind, our article sets out to investigate the consequences and implications of market choice in the context of frugal innovation.

The starting point of this investigation is profit driven by growth and expansion, which can be seen as the motivating factor behind the vast majority of business activities around the world. Therefore, firms across all industries are investing substantial resources into creating and sustaining continuous growth with their products, services and business models. This includes technological advances of products, the development of unique services, novel revenue models and much more. In order to succeed with these activities it is vital to study und understand the driving growth forces for customers and the market environment closely. Overall, companies tend to regard their existing customers as the critical information source for the conception of new solutions and offerings in order to grow profitably. Until recently, mostly people in Western markets or high-income segments fuelled the global economic growth and by this shaped products and services. This situation leaves many people around the globe in an almost vacuum-like state, when it comes to active participation in the formal economy (Hart and Christensen, 2002). However, many of the industrialised markets experienced and experience financial crises and recessions, resulting in stagnating incomes and increasing unemployment rates (Rao, 2013). This is particularly the case for their middle classes, which represent the economical backbone in most of these countries. Simultaneously, the global community has to deal with an ever-growing world population, forcing all of us to think of ways to reduce resource consumption and reconsider our approach to innovation (Brem and Ivens, 2013). As the global economic situation is changing drastically, new markets are gravitating towards the centre of attention when it comes to growth opportunities. Already today, emerging and developing markets represent $70 \%$ of the global economic growth (IMF, 2016). By now, politics, industry and academia have widely recognised the (mostly untapped) potential of emerging and developing markets and the economic growth prospects connected to them (Prabhu et al., 2017). Many countries in Asia, Africa and Latin America develop rapidly and consequently offer new markets and growth opportunities for local and international companies. Despite the obvious growth opportunities for businesses, one increasing focus in these new markets has been on innovation around social or sustainability aspects (Rosca et al., 2018; George et al., 2012). Recent years have seen an increased interest and attention among practitioners and in the scientific discourse on innovations that explicitly target market and customer segments in emerging and developing markets. One increasingly growing stream in this field is the debate around frugal innovation. This term described specifically (re)designed products, services or systems that explicitly cater to the needs of resource-constrained customers in underserved market segments, such as the so-called bottom of the pyramid (BoP) or the emerging middle class (Prahalad and Hammond, 2002; Prahaldad, 2012), across emerging and developing countries (Prabhu and Jain, 2015; Winterhalter et al., 2017; Zeschky et al., 2014). From a technology and market perspective, frugal 
innovations reportedly are based on a new product architecture, build with existing technology enabling new applications at a significantly lower price (Lehner and Gausemeier, 2016; Rego, 2014). After advancing quite substantially in Southeast Asia, China, India, Africa and Latin America, frugal innovation are increasingly finding their way into Western, industrialised markets. So far, the academic debate among scholars mostly focused on definitions and conceptual aspects of frugal innovation (Brem and Wolfram 2014; Soni and Krishnan 2014; Ray and Ray, 2010; Zeschky et al., 2011) even though the field is branching out to some extent. Overall, available cases show that frugal Innovation can take varying forms and cover a great bandwidth of customer segments, which are not restricted to specific market environments. Scholars argue that innovations, which target resource-constrained customers, particularly frugal innovation, are quite disruptive to the market environment they are introduced to (Wan et al., 2015). These distinctive forms of resource-constrained innovations are associated with a disruptive character (Zeschky et al., 2014), as they have the potential to reach BoP customers through significantly reducing the initial purchasing and/or total ownership costs and simultaneously providing a solution that fits optimally to the intended purpose considering the local conditions, while utilising as few resources as possible. In combination with additional functionalities, these innovations can even create entirely new-markets (Agarwal and Brem 2012, Prahalad 2012, Rao 2013, Zeschky, et al. 2014). Due to all these factors, an increasing number of firms as well as academics want to understand how frugal innovation can be realised successfully.

One central theme that continuously occurs in the discussions around and in publications dealing with frugal innovation is the market environment in emerging and developing countries itself. In many cases, they have been described as highly demanding to operate in and cater to, especially for Western firms, who have almost no preliminary experience with them (Anderson and Markides, 2007; London and Hart, 2004). In order to realise frugal innovations successfully, knowledge of the target market ${ }^{1}$ that oftentimes shapes the customers' needs is essential (Zeschky et al., 2014; Widenmayer and Gassmann, 2011; Williamson, 2010). Due to their inherent properties, emerging and developing markets create numerous constraints, such as institutional voids (Khanna and Palepu, 1997; 2000) or the absence or adequate infrastructure in form of electricity, water supply, sanitation, roads and other aspects (Ricart et al., 2004). Both firms and customers have to deal with these constraints (Hoskission et al., 2013) and consequently the innovation itself needs to overcome them successfully. This area seems to be a particular promising field due to the heterogeneity and novelty of the target segments of frugal innovation (Winterhalter et al., 2017). Further, many authors concentrate solely on the product or service perspective (Brem and Wolfram, 2014). Thus far, research has not investigated the consequences and implications of market choice in the context of frugal innovation. Therefore, this study will investigate the interplay between target market and the solution as it seems apparent that firms as well as scholars need to understand this critical interaction. From this, we will generate new insights that contribute to a deeper understanding of frugal innovation in academia and among practitioners. In the following, the research method is introduced, the findings are presented and implications and consequences are discussed in the context of current debates within the literature. 


\section{Method}

\subsection{Data collection}

As this publication investigates a new premise, the selected research approach was of exploratory nature. Consequently, this study is based on a multi-case study approach (cross-industry and cross-national), which allows for in-depth research. This is especially appropriate for the examination of novel research topics and contemporary phenomena as it allows to answer 'how' and 'why' questions (Yin, 2014; Eisenhardt, 1989). Before we started our analysis, extant literature regarding the topic under investigation was studied to generate a comprehensive research guide including an extensive questionnaire. Overall, our empirical analysis took place in three differentiated phases. First, our investigation commenced with the collection of 33 unique in-depth case studies spanning various industries ${ }^{2}$ and target markets [see Table 2, Figure 1 - underlined case numbers and Tables 3-6 (Appendix) - underlined case numbers]. The case studies were selected based on their fit to established definitions and descriptions in the literature concerning frugal innovation (see Weyrauch and Herstatt, 2014; Zeschky et al., 2014; Winterhalter et al. 2017). These cases are based on primary data, which was collected in form of 57 interviews that lasted between $45-90$ minutes (either face-to-face or via phone). Prior to the interviews, the guide was send to the interview partners to assure their proper preparation. All interviews were semi-structured and conducted following an iterative approach, continuously adapting the interview guideline with newly gained insights (Gibbert et al., 2008; Siggelkow, 2007). The interviewees of the different case firms were a combination of project members or executives from Western headquarters and the respective target markets or affiliated subsidiaries as well as the involved project members. After the interviews, the accumulated data was triangulated with internal company documents, we were granted access to (e.g., organisational charts, presentations and memos) and publicly available secondary data sources. This particular combination enabled us to achieve the most holistic portrayal of the innovation and its characteristics for our analysis. In order to gain a deeper understanding that goes beyond a limited number of case studies, we included 237 cases of frugal innovations, which we collected over a period of more than 8 years starting in 2009 (count includes 33 primary cases). This database was established to paint a more accurate picture of the on-going activities of frugal innovation around the globe. By incorporating various markets, including emerging, developing markets, as well as developed markets and all industries ${ }^{2}$ more general assumptions could be made. The products and services include among others: Large-scale energy projects (e.g., water turbines), industrial machines (e.g., garment twisting, food processing, packaging, laser cutting), consumer electronics (e.g., white goods, mobiles, tablets), agriculture equipment (tractors, milling machines, harvester), medical applications (e.g., ECGs, sterilisation, surgery procedures, infant care), water management (desalination, purification, extraction, provisioning), transport (cars, trucks, scooter, drones), finance (mobile payment, micro-insurance, ATMs), energy (solar, wind, bio-gas, gravity lamps, generators) and many more. 
Table 1 Case information focus of the data base (secondary data)

\begin{tabular}{c}
\hline Case information \\
Product name \\
Description \\
Company name \\
Global HQ (country) \\
Company size (start-up, SME, MNC) \\
Industry \\
Customer (B2B, B2C or hybrid) \\
Solution type (product, service or hybrid) \\
Technology know-how existed (yes or no) \\
Market entry (country/year) \\
Price (comparable price; \%) \\
Low-end or new-market disruption \\
\hline
\end{tabular}

Table 2 Case firm overview

\begin{tabular}{|c|c|c|c|}
\hline Case & Company description & $\begin{array}{c}\text { Employees } \\
\text { (approx.) }\end{array}$ & No. interviews \\
\hline 1 & Industrial technology & 140,000 & 3 \\
\hline $2-5$ & Chemical producers & 110,000 & 7 \\
\hline 6 & Thermal process engineering & 10,000 & 6 \\
\hline 7 & Home appliances & 60,000 & 2 \\
\hline 8 & Optical systems & 25,000 & 1 \\
\hline 9 & Agricultural machinery & 10,000 & 2 \\
\hline 10 & Financial self-service & 25,000 & 1 \\
\hline 11 & Applications for mobile living & 6,000 & 1 \\
\hline $12-13$ & Medical diagnostic imaging & 55,000 & 2 \\
\hline $14-15$ & Piping systems, machining and automotive & 15,000 & 1 \\
\hline 16 & Agricultural machinery & 2,000 & 1 \\
\hline 17 & Pumps and pump systems & 20,000 & 3 \\
\hline 18 & Building materials & 100,000 & 2 \\
\hline $19-20$ & Water management & $<20$ & 4 \\
\hline 21 & Medical devices & 6,000 & 2 \\
\hline 22 & Packaging solutions & 4,000 & 1 \\
\hline 23 & Medical equipment & 110,000 & 2 \\
\hline 24 & Energy production & $<20$ & 2 \\
\hline 25 & Medical imaging systems & $<20$ & 1 \\
\hline 26 & Polymer-based systems & 20,000 & 3 \\
\hline 27 & Twisting and cable machines & 10,000 & 1 \\
\hline 28 & Electronic power systems & 600 & 2 \\
\hline 29 & Wire processing & 2,500 & 2 \\
\hline $30-31$ & Medical imaging & 50,000 & 3 \\
\hline 32 & Medical equipment & $<20$ & 1 \\
\hline 33 & Medical imaging systems & 400 & 1 \\
\hline
\end{tabular}




\subsection{Data analysis}

In order to evaluate the cases appropriately we applied open coding as supported by Atlas Ti software. As a first step, open coding was performed by analysing sentences and phrases in all case interviews, searching for and categorising themes. To enhance the validity and reliability of our findings the collected data was triangulated with secondary sources (company documents and publicly available material) (Davis and Eisenhardt, 2011). This iterative alteration between data and emerging themes also diminished the biases regarding recall and rationalisation and thus increased the consistency of the results (Locke, 2001; Miles and Huberman, 1994). Applying this method, we were able to identify four distinct clusters of frugal innovation. In a second step, we consulted the secondary data (case database) to validate our preliminary findings. Further, we subjected this data to an analysis to assign each case to a specific cluster. The available data was again analysed independently with Atlas Ti by the authors and the two research assistants (Mayring, 2007), identical to the data in the first phase. From this, we were able to confirm the identified clusters based on the 33 primary cases. In a third phase, we further consolidated the results of the first two phases. We analysed all clusters comprehensively, thus achieving a better understanding of the interplay between all factors involved and the consequent manifestation of characteristics of an innovation, as well as the underlying mechanisms and strategic implications that the market choice yields. All analyses passed through various iterations until the findings generated a strong and consistent picture.

\section{Findings}

Analysis of the 237 cases in this study revealed two distinct aspects regarding frugal innovation. Firstly, it became apparent that the frugal innovations analysed in this study are always disruptive to the market environment they were introduced to. At this point, it has to be acknowledged that not every product or service that is merely offered to people in low or middle-income segments in emerging or developing markets is simply disruptive by nature. Yet, the innovations analysed in this study constitute this label as they significantly influenced or changed the respective markets they were introduced to. Generally, a disruptive innovation is considered to be something (often a product or service in the context of management research) that alters existing processes, activities or conditions. Further, drawing on the definitions by Christensen and Raynor (2003), frugal innovations fall either into the category of low-end disruptions or new-market disruptions. Low-end disruptions are defined as an offering that targets customers at the lower end of the respective market, which are often underserved in terms of available market offering. Through these new offerings the market dynamics are disrupted and the customer suddenly finds her- or himself in a position of choice through executing their buying power. The customer is no longer as limited in their choice as before. On the other hand, new-market disruptions always compete against non-consumption in the early stages and thereby create entirely new markets in the first place. Alternative solutions competing with these products or services are either completely out of financial or geographical reach for the targeted customer or do not exist at all. Frugal innovation that fall into this category therefore faces no comparable competition and incumbents are absence in most markets. Thus, by offering a solution on an industrial scale the customer 
of these so-called new-market disruptions become first-time participants (i.e., customers) in the global formal economy. Later, these innovations pull customers from the original value network seeking solutions that are more affordable to own and simpler to use. Secondly, the activity focus of the firms varies depending on the market choice. For some frugal innovations the focus is placed on activities along the value chain and less on the solution itself. Here, the main focus is cost savings in the processes to make the product or service more affordable. For other frugal innovations the opposite is the case. The solution is at the centre of all activities and the value chain (activities) follows accordingly. The starting point here is the customer's need for a specific solution, which is then designed to specifically serve these needs. As in the frugal innovations with a larger focus on activities, these solution focussed projects also make adaptations to their existing value chains. However, in some cases, due to the novelty of the product or service the necessary value chain is set-up from scratch and tailored to the respective needs of the solution and the customer's environment (e.g., last-mile challenge, micro-factories) as well. Based on a two-folded differentiation four distinct clusters of frugal innovation were derived in this study. The resulting x-axis was labelled impact on market (low-end disruption and new market disruption) and the y-axis activity focus (value chain and product/service) (see Figure 1). In the following sections, the findings per cluster are presented in greater detail. Additionally, for each cluster the focus of typical firms regarding the four aspects strategy, organisation, processes and technology was rated (high $=3$; medium $=2$; low $=1$ ) in comparison to the other clusters (see Figures 2-5).

Figure 1 The resulting four clusters of the analysed cases $(\mathrm{n}=237)$

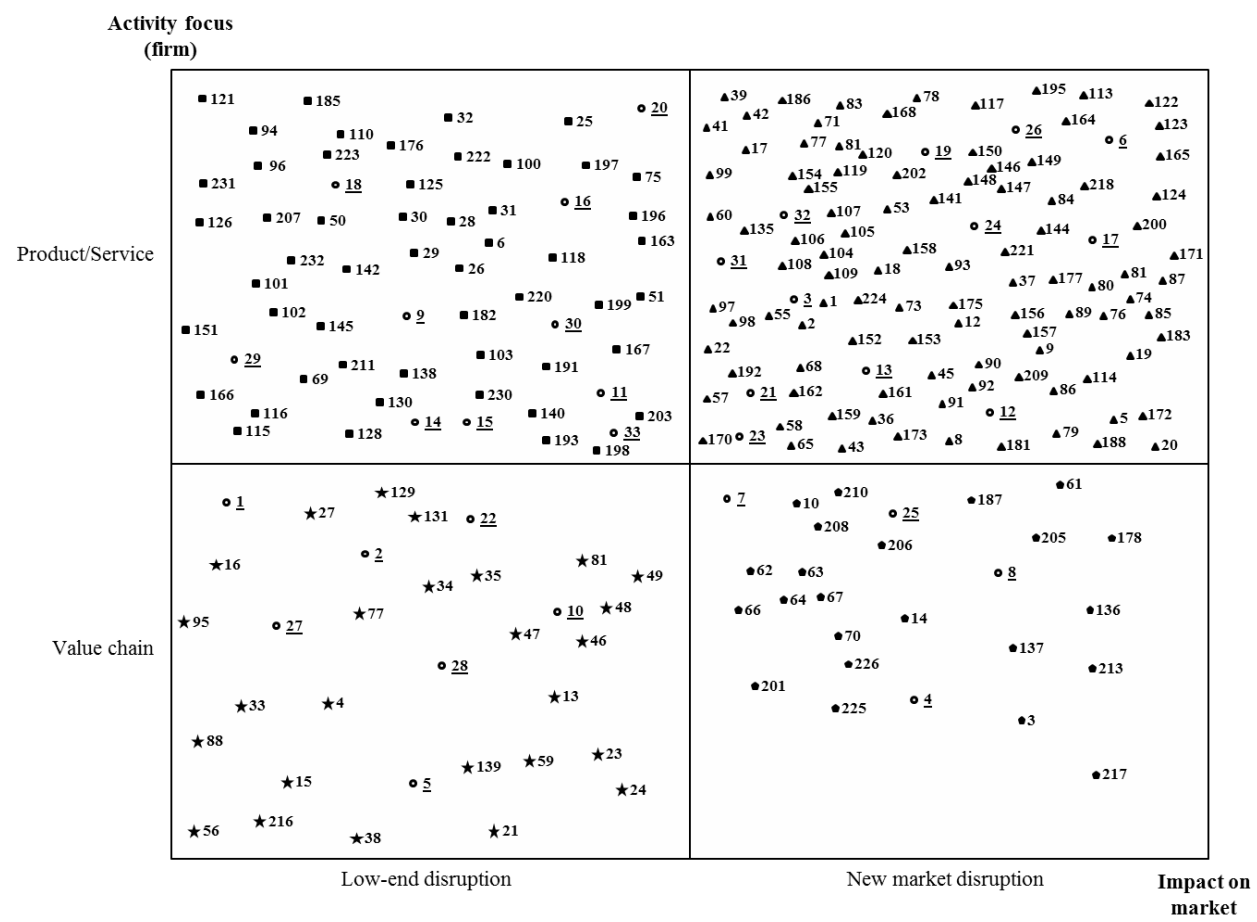




\subsection{Cluster 1 (value chain/low-end disruption)}

The frugal innovations in this cluster are characterised by a focus on substantial cost reduction during the value creation process and a concentration on core functionalities that lead to an optimised performance level. However, all solutions in this cluster are based on existing products or services and compete with other (local or regional) low-cost competitors, thus creating so-called low-end disruption in the target market. The solutions in these markets include large-scale water turbines, vacuum packaging machines, low-cost cars, bikes or scooter. Competition in these markets is based mainly on cost advantages, efficiency enhancements or a combination of both. In many cases, these innovations target B2B customers in China, India, Indonesia or the emerging middle-class in countries summarised under terms such as BRIICS ${ }^{3}, \mathrm{MINT}^{4}$ or the Next $11^{5}$. These customers are looking for industrial machines or products offered at a very low price, whoever still good-enough in their functionality and output. These markets often already offer high-end products that are sold in Western markets or very cheap local solutions that do not stand the test of time. The final frugal innovation solutions are adapted to be operated more easily by less qualified personal (e.g., simple touch displays), operated with less personal (e.g., less program variability) or the de-automation of certain steps in the process as it is cheaper to perform them manually, due to low labour costs in the target markets (e.g., packaging). When it comes to B2C products or services in this cluster, functionality changes by reduction or adaptation to the specific context of use. Cars or motorcycles for example offer less comfort, are more robust and are easier to maintain compared to their Western counterparts. In terms of strategy and technology, the focus of the case firms was rather low. The overall strategy of companies in this cluster was not adjusted and the required technology existed either from previous generations or in related industries. However, for firms to be successful in this cluster, it is important to focus on the activities along the value chain as most value is generated by improving efficiency and effectiveness. Further, from an organisational perspective firms need to challenge their current practices and as we saw in many cases adapt or build the value chain from scratch. Even though targeted at a much larger customer base, these solutions are identical across all global markets and do not require or offer local/regional adaptations. Unfortunately, these solutions appeal only to a smaller proportion when it comes to Western customers, as these products and services are associated with low quality and in some cases do not meet the high Western safety standards. A positive example of a product that would fit into this category, which fares well in Western and emerging markets, are Dacia's low-cost cars. In terms of industries most firms in this cluster are from the sectors of machine engineering (e.g., production machines or components), automotive/transportation (e.g., cars or motorcycles) or financial services (e.g., ATMs). Other industries included are low-cost software applications or communication solutions (see Table 3). 
Figure 2 Cluster $1($ high $=3$; medium $=2 ;$ low $=1)$

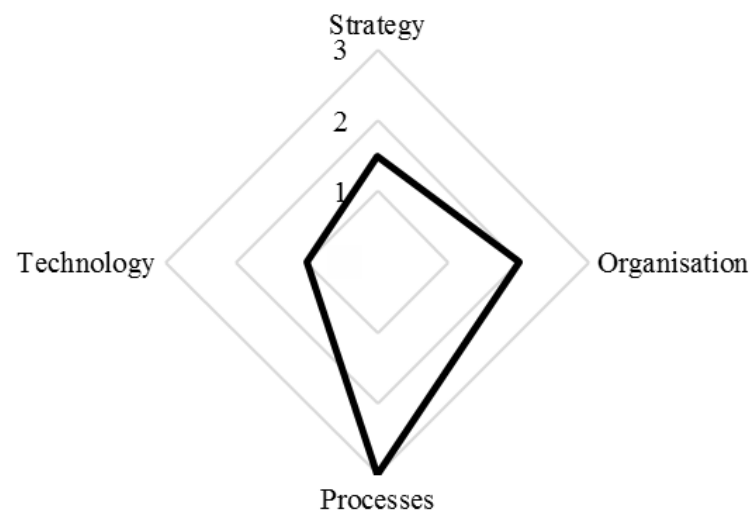

\subsection{Cluster 2 (product/service/low-end disruption)}

The frugal innovation cases in the second cluster are characterised by product or service adaptations to suit the exact needs of the target customer in their respective context. In this cluster, the solution is at the centre of attention regarding the firm's activities. Products or services in this cluster are for example agricultural machines that are specifically adapted to fit local needs or water management systems for farmers. The value chains of the firms are adapted accordingly to create and enable the solution, which was developed specifically to these underserved customers. Innovations in this category are based on existing products; however vary substantially in terms of characteristics and most often their business model as well. Products are not simple sold but often rented, leased, financed or combined with additional value adding features such as mobile applications that for example distribute crucial knowledge. As in the first cluster, these innovations cause low-end disruption in their markets but do compete more successfully against existing solutions, as they are tailored more specifically to the needs of local customers and their environment. In addition, these innovations primarily target the emerging middle class customer in emerging markets (see cluster 1) or rather advanced segments in developing markets for example in Kenya or Bolivia. The majority of products in this cluster can be found in the healthcare sector, followed by agriculture (e.g., tractors), machine engineering (e.g., industrial scales) and energy-related solutions (e.g., lights). Other products target the construction (e.g., concrete), cooking (e.g., stoves) or water management (e.g., measurement tools) segment. Products in this cluster include fMRI, X-ray machines or diagnostic test that are significantly cheaper and much easier to handle by the local staff. The same is true for the energy category with turbines, wind, solar and light solutions. Further, machines for the use in agriculture or production are functionally adapted to match the exact needs of local people. Here, it is remarkable that products do not simple have less but specific functions that are often only available in this particular frugal innovation and not in their Western counterparts. These types of innovations enables firms to offer their solutions at a much lower price point and simultaneously focus on core functionalities and optimised performance levels for the customer. Another factor that sets this cluster apart from the first is the fact that firms focussed much stronger on the environmental impact and the longevity of their solutions. 
Besides, the product adaptations many solutions in this group were also coupled with new business models such as leasing or pay-per-use to account for the fact that people in these markets are not able to immediately come up with the money to pay for a tractor or the like. Entering markets as they are described here requires a strong focus on strategy and technology as firms are departing from their original solutions and established value chains. Arguably the organisation itself and the processes need to be adapted but do follow strategy and technology respectively.

Figure 3 Cluster $2($ high $=3$; medium $=2$; low $=1)$

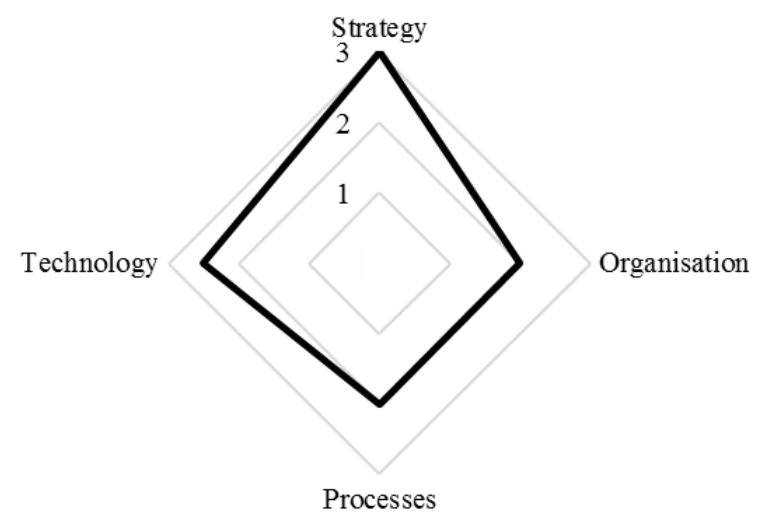

\subsection{Cluster 3 (value chain/new market disruption)}

Perhaps, one could describe the frugal innovations in this cluster as the most radical cases in this study. All products and services are based on a new product architecture, which enables entirely new applications and simultaneously offer an optimised performance level with a concentration on core functionalities at a much lower price. The firms responsible for the frugal innovations, reported that they developed their solutions from scratch focussing on simplicity and convenience thus ending up with very radical innovations. These solutions are the first of their kind, aiming at the so-called non-customer and thus creating new-market disruption. These frugal innovations face no competition from neither local nor international firms. The only alternative to these solutions is non-consumption as described earlier. Without these products or services, the targeted customers are simply excluded from participation in the formal economy. The solutions represented by this cluster are off-grid energy solutions, medical products for disinfection or mobile maize processing units for the agricultural business as well as meteorological services. In most cases, the solutions in this cluster cater to the fulfilment of basic needs in emerging and developing markets targeting customers from the BoP up to the emerging middle class. This includes housing (affordable and sustainable shelter), healthcare (neonatal/infant care, diagnostics, portable and robust solutions), water management (purification and measurement), energy (off-grid sustainable power generation, light, food preparation) and financial services (mobile banking/money and micro insurances) (see Table 5). Overall, three aspects stand out for the frugal innovations in this cluster. Firstly, these solutions in many cases transform formerly B2B markets into B2C. This is necessary due to the absence of a formal industry sector or institutions in the market environment. Thus, people need to serve themselves by using 
for example off-grid energy solutions. Secondly, almost all solutions either encompass a digital component itself or rely on digital infrastructure during the usage. Through this, missing infrastructure in the particular markets can be substituted and/or costly physical components can be potentially avoided. Some solutions are digitised completely from the start such as micro-insurances and mobile banking solutions making physical branches or the like superfluous. Thirdly, many of the solution in this cluster are applicable beyond their intended segments and increasingly find their way into Western markets as well. Especially, solutions from the healthcare, energy and financial services sector become increasingly popular among Western customers due to their simplicity and convenience offered at a very low price point. This holds true for B2C as well as for B2B solutions and across industries. Even though the potential customer base is huge, firms need to be aware of the challenges involved when targeting these kinds of markets. Creating a frugal innovation that falls into this cluster is certainly the most demanding in terms of strategy, organisational setup including the processes as well as the development of specifically tailored innovations targeting people are considered as are non-customers in most aspects of their lives.

Figure 4 Cluster $3($ high $=3$; medium $=2$; low $=1)$

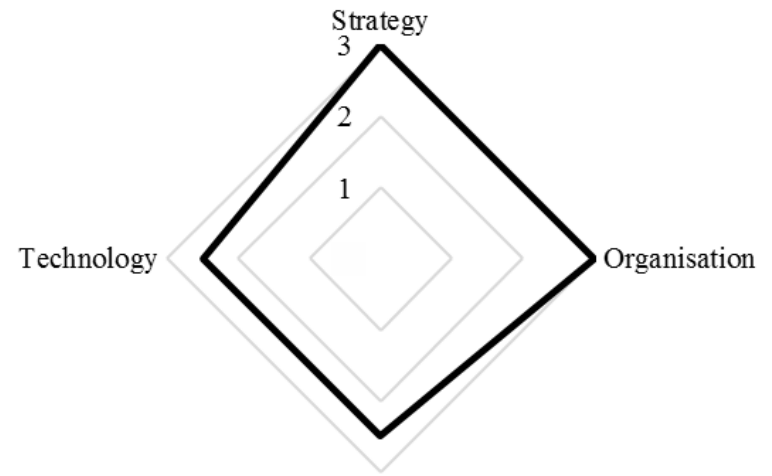

Processes

\subsection{Cluster 4 (product/service/new market disruption)}

Innovations in the fourth and last cluster again target non-existing customers, thereby creating entirely new markets respectively new market disruption. Competition for these solutions does either not exist or is out of financial or geographical reach to the intended customer. This cluster contains two main categories (see Table 6). The first is composed of mainly low-grade 'entry' technology and electronics (e.g., white goods, communication technology or consumer electronics). These technologies have been out of reach for customers in the targeted markets mainly due to high prices and a lack of availability. People in lower income classes of emerging markets and the rising middle class in developing markets become first time eligible customer through these offerings. The second category in this cluster contains modified services and procedures in the medical and education sector that focus on efficiency to be affordable for customers in the emerging middle class but also to people at the BoP. Offers are for example the dispensation of medicine, delivery of surgeries and other emergency services such as 
ambulances. In addition, educational services are offered for the first time by integrating digital components, which substitute costly or unavailable physical ones (e.g., teaching material). Further, certain services are only possible because the revenue model varies significantly from its Western counterparts. Most innovations in this cluster have a strong focus on the creation of efficiencies throughout the value chain to deliver an affordable product or service. Especially, the medical and educational services are based on innovative ways of service delivery. The products itself are adapted only to the extent that they reach the required price point and that certain functions cater to the environment they are used in. In terms of focus, the firms in this cluster reported that the processes and the strategy are at the heart of their activities. Targeting customers that fall into this cluster requires a new strategy and processes that are efficient and effective to reach the required prices and function. Further, the organisation needs to be adapted significantly especially towards the end of the value creation, i.e., in the service delivery that happens in the markets itself. In terms of technology, all cases apply existing solutions that are recombined or repurposed. In none of the cases do we see newly developed components. Firms in this cluster rely on the innovative use of existing technology or recombination.

Figure 5 Cluster $4($ high $=3$; medium $=2 ;$ low $=1)$



\section{Discussion}

This study provides insights on the consequences and implications of market choice regarding frugal innovation. In particular, this research finds that all frugal innovations studied here create one of two forms of disruption. These products and services create either a low-end disruption or even a new-market disruption in the market they target. One could even argue that frugal innovations that create new-market disruptions also create low-end disruption as these often deliver requirements and prerequisites that go beyond the basic needs of the target markets. Overall, the cases in this study reinforce the notion that frugal innovations are disruptive innovations as suggested by earlier studies (Christensen and Raynor, 2003; Markides, 2006; Wan et al., 2015). While extant research has already highlighted that resource-constrained innovations create new low-cost segments of existing markets (Hang et al., 2010) this study suggests that resource-constrained innovation create new markets if they entail new application 
innovations. These discoveries add to the growing body of literature that explores under which circumstances and conditions disruptive innovations can be achieved. As disruptive innovations are seen as an important phenomenon in competitive strategy and thus for the growth of a company, this moves frugal innovation further towards the centre of attention for both managers and academics. In line with suggestions of earlier studies (Wan et al., 2015; Hart and Christensen, 2002; Li, 2013) emerging and developing economies have been found to be a crucial source of disruptive innovation for firms. The environments and circumstances in these markets stimulate disruptive innovation as they challenge established designs, processes, structures and business models. By shaping the needs of the customer, the market environment shapes the manifestation of the characteristics of a specific frugal innovation. The significantly different market and institutional environment in emerging markets forces firms to tailor their solutions, structures and processes to meet the challenges in these markets to address the target customer. Thus, the market of choice determines the approach a firm follows in their frugal innovation endeavour to a large extend. This is a crucial realisation, as it is important to understand the driving forces behind these innovations to make them more predictable and manageable. Consequently, firms need to be aware what the market and the targeted customer group call for. Some require an adaption of structures and processes to achieve appropriate price points, others adaptions to the solution to fit the local context. Therefore, taking this into account firms need to base their market entry decision on these characteristics. If a firm is not able to design a solution from scratch, including the structures and processes (new-market disruption), it might be wise to choose a market that rather requires a focus on structures and processes and to a lesser extent on the solution itself (low-end disruptions). This is often true for more mature markets such as for example China or Brazil. Countries that are in earlier stages of economic development such as Kenya, Nigeria or Uganda require in many cases a more demanding approach. Further, this study brings forth the idea that there are different types of frugal innovations and consequently different means and actions are required as well as an altered focus to achieve them. This not only helps understand the phenomenon of frugal innovation more deeply but also offers immediate guidance for firms venturing into emerging and developing markets. The four clusters reveal that the choice of target market requires the firms to focus on different aspects during the process. Further, it shows that markets are not to be differentiated geographically but rather by the type of disruption, the frugal innovation causes. Building on the insight that characteristics of the target market shape frugal innovations (Brem and Wolfram 2014, Lehner and Gausemeier 2016, Tiwari and Herstatt 2014, Weyrauch and Herstatt 2017), this paper contributes to a better understanding of the impact of market choice on the frugal innovation itself, linking the type of target market to the characteristics of innovation.

\section{Conclusions and further research}

This study offers first insights regarding the implications and consequences of market choice for frugal innovation. By introducing four distinct clusters of frugal innovation the widely used umbrella term is broken up, allowing academics and firms to understand the phenomenon more precisely and in the context of individual markets. These findings are particularly relevant due to the increasing significance of frugal innovation, which have 
been suggested as a potential means to unlock the tremendous growth potential that lies within emerging and developing markets. We believe this study is a valuable addition to earlier publications on frugal innovation for practitioners and scholars alike. Based on the findings presented in this study future research should further investigate the disruptive potential that might be inherent in frugal innovations and the growing body of evidence that suggests emerging markets are an important source of disruptive innovation. So far, disruption is mainly attributed with technology, products or business models, however not with the markets or customer segments itself. Insights generated here also add to the long-standing debate on whether disruptive innovations are created or discovered. It becomes apparent that it would be a vital next step to advance insights regarding frugal innovation by studying the context and circumstance the customer finds herself/himself in to identify the specific implications \& consequences. Derived from this, research should study how firms actually achieve disruptive innovation and what the exact role of the market in this is. This holds several new implications for the current structures and processes in established innovation practice. Another path of inquiry in the context of these findings is the challenge of ambidexterity that Western firms have to tackle by catering to an ever-increasing range of customers across varying market segments. Handling both high-end innovation and frugal innovation in one company is a severely underexplored theme that requires in-depth empirical investigation. Lastly, since these findings again based on qualitative data from case studies, research in the field of frugal innovation should start investigations based on quantitative data to further add to the discussion in academia and provide firms with deeper insights.

Our findings also hold several managerial implications. Firstly, managers need to understand the consequences and implications of market choice concerning innovation, specifically regarding innovation for emerging and developing markets in great depths. Secondly, firms need to gain a deep understanding of their (new) target markets and the non-customer in order to serve them effective and efficiently. Thirdly, companies require a correct translation of their insights regarding customers and markets into specifically tailored strategic, processual, organisational and technological actions to develop solutions and business models in order to serve the targeted customer successfully.

\section{References}

Agarwal, N. and Brem, A. (2012) 'Frugal and reverse innovation - literature overview and case study insights from a German MNC in India and China', 2012 18th International ICE Conference on Engineering, Technology and Innovation (ICE), pp.1-11, IEEE.

Anderson, J. and Markides, C. (2007) 'Strategic innovation at the base of the pyramid', MIT Sloan Management Review, Vol. 49, No. 1, p.83.

Brem, A. and Ivens, B. (2013) 'Do frugal and reverse innovation foster sustainability? Introduction of a conceptual framework', Journal of Technology Management for Growing Economies, Vol. 4, No. 2, pp.31-50.

Brem, A. and Wolfram, P. (2014) 'Research and development from the bottom up - introduction of terminologies for new product development in emerging markets', Journal of Innovation and Entrepreneurship, Vol. 3, No. 1, p.9.

Christensen, C. and Raynor, M. (2003) The Innovator's Solution: Creating and Sustaining Successful Growth, Harvard Business Review Press, Boston.

Davis, J.P. and Eisenhardt, K.M. (2011) 'Rotating leadership and collaborative innovation recombination processes in symbiotic relationships', Administrative Science Quarterly, Vol. 56, No. 2, pp.159-201. 
Eisenhardt, K.M. (1989) 'Building theories from case study research', The Academy of Management Review, Vol. 14, No. 4, pp.532-550.

George, G., McGahan, A.M. and Prabhu, J. (2012) 'Innovation for inclusive growth: towards a theoretical framework and a research agenda', Journal of Management Studies, Vol. 49, No. 4, pp.661-683.

Gibbert, M., Ruigrok, W. and Wicki, B. (2008) 'What passes as a rigorous case study?', Strategic Management Journal, Vol. 29, No. 13, pp.1465-1474.

Hang, C., Chen, J. and Subramian, A. (2010) 'Developing disruptive products for emerging economies: lessons from Asian cases', Research Technology Management, Vol. 53, No. 4, pp.21-26.

Hart, S.L. and Christensen, C.M. (2002) 'The great leap: driving innovation from the base of the pyramid', MIT Sloan Management Review, Vol. 44, No. 1, p.51.

Horman, W. (1519) Vulgaria uiri doctissimi.

Hoskisson, R.E., Wright, M., Filatotchev, I. and Peng, M.W. (2013) 'Emerging multinationals from mid-range economies: the influence of institutions and factor markets', Journal of Management Studies, Vol. 50, No. 7, pp.1295-1321.

International Monetary Fund (IMF) (2016) Subdued Demand, Diminished Prospects, World Economic Outlook Update [online] http://www.imf.org/external/pubs/ft/weo/2016/update/01/ pdf/0116.pdf (accessed 13 June 2017).

Khanna, T. and Palepu, K. (1997) 'Why focused strategies may be wrong for emerging markets', Harvard Business Review, Vol. 75, No. 4, pp.41-48.

Khanna, T. and Palepu, K. (2000) 'The future of business groups in emerging markets: long-run evidence from Chile', Academy of Management Journal, Vol. 43, No. 3, pp.268-285.

Lehner, A. and Gausemeier, J. (2016) 'A pattern-based approach to the development of frugal innovations', Technology Innovation Management Review, Vol. 6, No. 3, pp.13-21.

Li, P. (2013) 'Introduction: disruptive innovation from the bottom of the pyramid', in Li, P. (Ed.): Disruptive Innovation in Chinese and Indian Businesses: The Strategic Implications for Local Entrepreneurs and Global Incumbents, Routledge, London.

Locke, K. (2001) Grounded Theory in Management Research, Sage, London.

London, T. and Hart, S.L. (2004) 'Reinventing strategies for emerging markets: beyond the transnational model', Journal of International Business Studies, Vol. 35, No. 5, pp.350-370.

Markides, C. (2006) 'Disruptive innovation: in need of better theory', Journal of Product Innovation Management, Vol. 23, No. 1, pp.19-25.

Mayring, P. (2007) 'Designs in qualitativ orientierter Forschung', Journal für Psychologie, Vol. 15, No. 2, pp.1-10.

Miles, M.B. and Huberman, M. (1984) Qualitative Data Analysis: A Sourcebook of New Methods, SAGE, Beverly Hills, CA.

Prabhu, J. and Jain, S. (2015) 'Innovation and entrepreneurship in India: understanding jugaad', Asia Pacific Journal of Management, Vol. 32, No. 4, pp.843-868.

Prabhu, J., Tracey, P. and Hassan, M. (2017) 'Marketing to the poor: an institutional model of exchange in emerging markets', AMS Review, Vol. 7, Nos. 3-4, pp.1-22.

Prahalad, C.K. (2012) 'Bottom of the pyramid as a source of breakthrough innovations', Journal of Product Innovation Management, Vol. 29, No. 1, pp.6-12.

Prahalad, C.K. and Hammond, A. (2002) 'Serving the world's poor, profitably', Harvard Business Review, Vol. 80, No. 9, pp.48-59.

Rao, B.C. (2013) 'How disruptive is frugal?', Technology in Society, Vol. 35, No. 1, pp.65-73.

Ray, P.K. and Ray, S. (2010) 'Resource-constrained innovation for emerging economies: the case of the Indian telecommunications industry', IEEE Transactions on Engineering Management, Vol. 57, No. 1, pp.144-156. 
Rego, A., Oliveira, P., Rosado, P. and Habib, N. (2014) 'Product innovation in resource-poor environments: three research streams', Journal of Product Innovation Management, Vol. 31, No. 2, pp.202-210.

Ricart, J.E., Enright, M.J., Ghemawat, P., Hart, S.L. and Khanna, T. (2004) 'New frontiers in international strategy', Journal of International Business Studies, Vol. 35, No. 3, pp.175-200.

Rosca, E., Reedy, J. and Bendul, J.C. (2018) 'Does frugal innovation enable sustainable development? A systematic literature review', The European Journal of Development Research, Vol. 30, No. 1, pp.136-157.

Siggelkow, N. (2007) 'Persuasion with case studies', The Academy of Management Journal, Vol. 50, No. 1, pp.20-24.

Soni, P. and Krishnan, R.T. (2014) 'Frugal innovation: aligning theory, practice, and public policy', Journal of Indian Business Research, Vol. 6, No. 1, pp.29-47.

Wan, F., Williamson, P.J. and Yin, E. (2015) 'Antecedents and implications of disruptive innovation: evidence from China', Technovation, Vol. 39, pp.94-104.

Weyrauch, T. and Herstatt, C. (2017), What is frugal innovation? Three defining criteria', Journal of Frugal Innovation, Vol. 2, No. 1, p.1.

Williamson, P. (2010) 'Cost innovation: preparing for a 'value-for-money' revolution', Long Range Planning, Vol. 43, pp.343-353.

Winterhalter, S., Zeschky, M.B., Neumann, L. and Gassmann, O. (2017) 'Business models for frugal innovation in emerging markets: the case of the medical device and laboratory equipment industry', Technovation, Vol. 66, pp.3-13.

Yin, R.K. (2014) Case Study Research: Design and Methods, 5th ed., Thousand Oaks Sage.

Zeschky, M., Widenmayer, B. and Gassmann, O. (2011) 'Frugal innovation in emerging markets', Research-Technology Management, Vol. 54, No. 4, pp.38-45.

Zeschky, M., Widenmayer, B. and Gassmann, O. (2014a) 'Organizing for reverse innovation in Western MNCs: the role of frugal product innovation capabilities', International Journal of Technology Management, Vol. 64, Nos. 2-4, pp.255-275.

Zeschky, M., Winterhalter, S. and Gassmann, O. (2014b) 'From cost to frugal and reverse innovation: mapping the field and implications for global competitiveness', Research-Technology Management, Vol. 57, No. 4, pp.20-27.

\section{Notes}

1 The terms 'market' and 'segment' are used interchangeably throughout this publication, as both refer to the group of target customers that are being addressed with the product or service under investigation.

2 This study purposefully excluded fast-moving consumer goods (FMCGs) since these products in many cases are already adapted for each market (country) and resort to smaller package sizes when it comes to serving emerging and developing market clients.

3 BRIICS - Brazil, Russia, India, Indonesia, China and South Africa.

4 MINT - Mexico, Indonesia, Nigeria and Turkey.

5 Next 11 - Bangladesh, Egypt, Indonesia, Iran, Mexico, Nigeria, Pakistan, Philippines, Turkey, South Korea, Vietnam. 


\section{Appendix}

Table 3 Cluster 1

\begin{tabular}{|c|c|c|}
\hline Case & Industry & Product/service \\
\hline$\underline{1}$ & Energy & $P$ \\
\hline$\underline{2}$ & Food & $\mathrm{P}$ \\
\hline$\underline{5}$ & Clothing & $\mathrm{P}$ \\
\hline$\underline{10}$ & IT & $\mathrm{P}$ \\
\hline$\underline{22}$ & Machine engineering & $\mathrm{P}$ \\
\hline$\underline{27}$ & Machine engineering & $\mathrm{P}$ \\
\hline$\underline{28}$ & Electronic & $\mathrm{P}$ \\
\hline 4 & Agriculture & $\mathrm{P}$ \\
\hline 13 & Other & $P$ \\
\hline 15 & Agriculture & $P$ \\
\hline 16 & Machine engineering & $P$ \\
\hline 21 & Service platform & S \\
\hline 23 & Motorcylce & $\mathrm{P}$ \\
\hline 24 & Automotive & $\mathrm{P}$ \\
\hline 27 & Automotive & $\mathrm{P}$ \\
\hline 33 & Automotive & $P$ \\
\hline 34 & Automotive & $\mathrm{P}$ \\
\hline 35 & Automotive & $\mathrm{P}$ \\
\hline 38 & Service platform & S \\
\hline 46 & Financial services & $\mathrm{P}$ \\
\hline 47 & Financial services & $\mathrm{P}$ \\
\hline 48 & Financial services & $\mathrm{P}$ \\
\hline 49 & Financial services & $\mathrm{P}$ \\
\hline 56 & Software & S \\
\hline 59 & Hardware & $P$ \\
\hline 88 & Nutrition & $\mathrm{P}$ \\
\hline 95 & Machine engineering & $\mathrm{P}$ \\
\hline 129 & Machine engineering & $P$ \\
\hline 139 & Healthcare & $\mathrm{P}$ \\
\hline 216 & Communication & S \\
\hline
\end{tabular}


Table 4 Cluster 2

\begin{tabular}{|c|c|c|}
\hline Case & Industry & Product/service \\
\hline$\underline{9}$ & Agriculture & $\mathrm{P}$ \\
\hline$\underline{11}$ & Cooking & $\mathrm{P}$ \\
\hline$\underline{14}$ & Machine engineering & $\mathrm{P}$ \\
\hline$\underline{15}$ & Machine engineering & $\mathrm{P}$ \\
\hline$\underline{16}$ & Machine engineering & $\mathrm{P}$ \\
\hline$\underline{18}$ & Construction & $\mathrm{P}$ \\
\hline$\underline{20}$ & Water management & $\mathrm{P}$ \\
\hline$\underline{29}$ & Machine engineering & $\mathrm{P}$ \\
\hline$\underline{30}$ & Healthcare & $\mathrm{P}$ \\
\hline$\underline{33}$ & Healthcare & $\mathrm{P}$ \\
\hline 6 & Agriculture & $\mathrm{P}$ \\
\hline 25 & Agriculture & $P$ \\
\hline 26 & Construction & $\mathrm{P}$ \\
\hline 28 & Agriculture & $\mathrm{P}$ \\
\hline 29 & Agriculture & $\mathrm{P}$ \\
\hline 30 & Agriculture & $P$ \\
\hline 31 & Agriculture & $\mathrm{P}$ \\
\hline 32 & Automotive & $\mathrm{P}$ \\
\hline 50 & Construction & $\mathrm{P}$ \\
\hline 51 & Construction & $\mathrm{P}$ \\
\hline 69 & Consumer electronics & $\mathrm{P}$ \\
\hline 75 & Other & $P$ \\
\hline 94 & Energy & $\mathrm{P}$ \\
\hline 96 & Energy & $\mathrm{P}$ \\
\hline 100 & Energy & $\mathrm{P}$ \\
\hline 101 & Energy & $\mathrm{P}$ \\
\hline 102 & Energy & $\mathrm{P}$ \\
\hline 103 & Energy & $\mathrm{P}$ \\
\hline 110 & Energy & $\mathrm{P}$ \\
\hline 115 & Energy & $\mathrm{P}$ \\
\hline 116 & Energy & $\mathrm{P}$ \\
\hline 118 & Energy & $\mathrm{P}$ \\
\hline 121 & Energy & $\mathrm{P}$ \\
\hline 125 & Energy & $\mathrm{P}$ \\
\hline
\end{tabular}


Table 4 Cluster 2 (continued)

\begin{tabular}{|c|c|c|}
\hline Case & Industry & Product/service \\
\hline 126 & Industrial instruments & $\mathrm{P}$ \\
\hline 128 & Machine engineering & $\mathrm{P}$ \\
\hline 130 & Machine engineering & $\mathrm{P}$ \\
\hline 138 & Healthcare & $\mathrm{P}$ \\
\hline 140 & Healthcare & $P$ \\
\hline 142 & Healthcare & $P$ \\
\hline 145 & Healthcare & $\mathrm{P}$ \\
\hline 151 & Healthcare & $\mathrm{P}$ \\
\hline 163 & Healthcare & $P$ \\
\hline 166 & Healthcare & $\mathrm{P}$ \\
\hline 167 & Healthcare & $\mathrm{P}$ \\
\hline 176 & Healthcare & $\mathrm{P}$ \\
\hline 182 & Healthcare & $\mathrm{P}$ \\
\hline 185 & Healthcare & $\mathrm{P}$ \\
\hline 191 & Healthcare & $P$ \\
\hline 193 & Healthcare & $\mathrm{P}$ \\
\hline 196 & Healthcare & $\mathrm{P}$ \\
\hline 197 & Healthcare & $\mathrm{P}$ \\
\hline 198 & Healthcare & $\mathrm{P}$ \\
\hline 203 & Healthcare & $\mathrm{P}$ \\
\hline 207 & Consumer electronics & $P$ \\
\hline 211 & Water management & S \\
\hline 220 & Cooking & $P$ \\
\hline 222 & Cooking & $P$ \\
\hline 223 & Cooking & $P$ \\
\hline 230 & Healthcare & $P$ \\
\hline 231 & White goods & $\mathrm{P}$ \\
\hline 232 & Machine engineering & $P$ \\
\hline
\end{tabular}


Table 5 Cluster 3

\begin{tabular}{|c|c|c|}
\hline Case & Industry & Product/service \\
\hline$\underline{3}$ & Housing & $\mathrm{P}$ \\
\hline$\underline{6}$ & Machine engineering & $\mathrm{P}$ \\
\hline$\underline{13}$ & Healthcare & $\mathrm{P}$ \\
\hline$\underline{17}$ & Water management & $\mathrm{P}$ \\
\hline$\underline{19}$ & Water management & S \\
\hline$\underline{21}$ & Healthcare & $\mathrm{P}$ \\
\hline$\underline{23}$ & Healthcare & $\mathrm{P}$ \\
\hline$\underline{24}$ & Energy & $\mathrm{P}$ \\
\hline$\underline{26}$ & Energy & $\mathrm{P}$ \\
\hline$\underline{30}$ & Healthcare & $\mathrm{P}$ \\
\hline 31 & Healthcare & $\mathrm{P}$ \\
\hline$\underline{32}$ & Healthcare & $\mathrm{P}$ \\
\hline 1 & Housing & $\mathrm{P}$ \\
\hline 2 & Housing & $\mathrm{P}$ \\
\hline 5 & Agriculture & $\mathrm{P}$ \\
\hline 8 & Other & $P$ \\
\hline 9 & Agriculture & $\mathrm{P}$ \\
\hline 12 & Agriculture & $\mathrm{P}$ \\
\hline 17 & Platform & S \\
\hline 18 & Agriculture & $\mathrm{P}$ \\
\hline 19 & Meteorology & S \\
\hline 20 & Platform & S \\
\hline 22 & Water management & S \\
\hline 36 & Healthcare & S \\
\hline 37 & Financial services & S \\
\hline 39 & Financial services & S \\
\hline 41 & Financial services & S \\
\hline 42 & Financial services & S \\
\hline 43 & Financial services & S \\
\hline 45 & Financial services & S \\
\hline 53 & Energy/education & S \\
\hline 55 & Housing & $\mathrm{P}$ \\
\hline 57 & Consumer electronics & $\mathrm{P}$ \\
\hline 58 & Air purification & $P$ \\
\hline 60 & Consumer electronics & $\mathrm{P}$ \\
\hline 65 & Consumer electronics & $P$ \\
\hline 68 & Consumer electronics & $P$ \\
\hline 71 & Hygiene & $\mathrm{P}$ \\
\hline
\end{tabular}


Table 5 Cluster 3 (continued)

\begin{tabular}{|c|c|c|}
\hline Case & Industry & Product/service \\
\hline 73 & Hygiene & $P$ \\
\hline 74 & Water management & $\mathrm{P}$ \\
\hline 76 & Water management & $\mathrm{P}$ \\
\hline 77 & Hygiene & $\mathrm{P}$ \\
\hline 78 & Other & $\mathrm{P}$ \\
\hline 79 & White goods & $P$ \\
\hline 80 & Water management & $\mathrm{P}$ \\
\hline 81 & Hygiene & $\mathrm{P}$ \\
\hline 83 & Hygiene & $\mathrm{P}$ \\
\hline 84 & Hygiene & $\mathrm{P}$ \\
\hline 85 & Water management & $\mathrm{P}$ \\
\hline 86 & Water management & $\mathrm{P}$ \\
\hline 87 & Water management & $\mathrm{P}$ \\
\hline 89 & Water management & $\mathrm{P}$ \\
\hline 90 & Water management & $P$ \\
\hline 91 & Water management & $\mathrm{P}$ \\
\hline 92 & Water management & $\mathrm{P}$ \\
\hline 93 & Cooking & $\mathrm{P}$ \\
\hline 97 & Energy & $\mathrm{P}$ \\
\hline 98 & Energy & $\mathrm{P}$ \\
\hline 99 & Water management & $\mathrm{P}$ \\
\hline 104 & Energy & $\mathrm{P}$ \\
\hline 105 & Energy & $\mathrm{P}$ \\
\hline 106 & Energy & $\mathrm{P}$ \\
\hline 107 & Energy & $\mathrm{P}$ \\
\hline 108 & Energy & $\mathrm{P}$ \\
\hline 109 & Energy & $\mathrm{P}$ \\
\hline 113 & Energy & $\mathrm{P}$ \\
\hline 114 & Energy & $\mathrm{P}$ \\
\hline 117 & Energy & $\mathrm{P}$ \\
\hline 119 & Energy & $\mathrm{P}$ \\
\hline 120 & Energy & $\mathrm{P}$ \\
\hline 122 & Energy & $\mathrm{P}$ \\
\hline 123 & Energy & $\mathrm{P}$ \\
\hline 124 & Energy & $\mathrm{P}$ \\
\hline 135 & Healthcare & $\mathrm{P}$ \\
\hline 141 & Healthcare & $\mathrm{P}$ \\
\hline 144 & Healthcare & $P$ \\
\hline
\end{tabular}


Table 5 Cluster 3 (continued)

\begin{tabular}{|c|c|c|}
\hline Case & Industry & Product/service \\
\hline 146 & Healthcare & $P$ \\
\hline 147 & Healthcare & $P$ \\
\hline 148 & Healthcare & $P$ \\
\hline 149 & Healthcare & $\mathrm{P}$ \\
\hline 150 & Healthcare & $\mathrm{P}$ \\
\hline 152 & Healthcare & $\mathrm{P}$ \\
\hline 153 & Healthcare & $\mathrm{P}$ \\
\hline 154 & Healthcare & $\mathrm{P}$ \\
\hline 155 & Healthcare & $\mathrm{P}$ \\
\hline 156 & Healthcare & $\mathrm{P}$ \\
\hline 157 & Healthcare & $\mathrm{P}$ \\
\hline 158 & Healthcare & $\mathrm{P}$ \\
\hline 159 & Healthcare & $P$ \\
\hline 161 & Healthcare & $\mathrm{P}$ \\
\hline 162 & Healthcare & $\mathrm{P}$ \\
\hline 164 & Healthcare & $\mathrm{P}$ \\
\hline 165 & Healthcare & $\mathrm{P}$ \\
\hline 168 & Healthcare & $P$ \\
\hline 170 & Healthcare & $\mathrm{P}$ \\
\hline 171 & Healthcare & S \\
\hline 172 & Healthcare & $\mathrm{P}$ \\
\hline 173 & Healthcare & $\mathrm{P}$ \\
\hline 175 & Healthcare & $\mathrm{P}$ \\
\hline 177 & Healthcare & $\mathrm{P}$ \\
\hline 181 & Healthcare & $\mathrm{P}$ \\
\hline 183 & Healthcare & $\mathrm{P}$ \\
\hline 186 & Healthcare & $\mathrm{P}$ \\
\hline 188 & Healthcare & $P$ \\
\hline 192 & Healthcare & $\mathrm{P}$ \\
\hline 195 & Healthcare & $\mathrm{P}$ \\
\hline 200 & Healthcare & $\mathrm{P}$ \\
\hline 202 & White goods & $P$ \\
\hline 209 & Other & S \\
\hline 212 & Healthcare & $\mathrm{P}$ \\
\hline 218 & Cooking & $P$ \\
\hline 221 & White goods & $\mathrm{P}$ \\
\hline 224 & Energy & $\mathrm{P}$ \\
\hline 227 & Energy & $\mathrm{P}$ \\
\hline 228 & Industrial instruments & $\mathrm{P}$ \\
\hline 229 & Energy & $\mathrm{P}$ \\
\hline
\end{tabular}


Table 6 Cluster 4

\begin{tabular}{|c|c|c|}
\hline Case & Industry & Product/service \\
\hline$\underline{4}$ & Nutrition & $\mathrm{P}$ \\
\hline$\underline{7}$ & White goods & $\mathrm{P}$ \\
\hline$\underline{8}$ & Healthcare & $\mathrm{P}$ \\
\hline$\underline{25}$ & Healthcare & $\mathrm{P}$ \\
\hline 3 & Nutrition & $\mathrm{P}$ \\
\hline 10 & Agriculture & $\mathrm{P}$ \\
\hline 14 & Energy & $\mathrm{P}$ \\
\hline 61 & Consumer electronics & $\mathrm{P}$ \\
\hline 62 & Communication & $\mathrm{P}$ \\
\hline 63 & Consumer electronics & $\mathrm{P}$ \\
\hline 64 & Consumer electronics & $\mathrm{P}$ \\
\hline 66 & Communication & $\mathrm{P}$ \\
\hline 67 & Communication & $\mathrm{P}$ \\
\hline 70 & Consumer electronics & $\mathrm{P}$ \\
\hline 136 & Healthcare & $\mathrm{S}$ \\
\hline 137 & Consumer electronics & $\mathrm{P}$ \\
\hline 178 & Healthcare & $\mathrm{S}$ \\
\hline 187 & Healthcare & $\mathrm{S}$ \\
\hline 201 & Healthcare & $\mathrm{S}$ \\
\hline 205 & Healthcare & $\mathrm{S}$ \\
\hline 206 & Education & S \\
\hline 208 & Agriculture & S \\
\hline 210 & Logistics & S \\
\hline 213 & Shopping & $\mathrm{S}$ \\
\hline 217 & Communication & S \\
\hline 225 & Education & $\mathrm{S}$ \\
\hline 226 & Education & $\mathrm{S}$ \\
\hline
\end{tabular}

